Article

\title{
The EU Emissions Trading System and Renewable Energy Policies: Friends or Foes in the European Policy Mix?
}

\author{
Marie Byskov Lindberg ${ }^{1,2}$ \\ ${ }^{1}$ TIK Centre for Technology, Innovation and Culture, University of Oslo, 0317 Oslo, Norway; E-Mail: m.b.lindberg@tik.uio.no \\ 2 Bavarian School of Public Policy, Technical University of Munich, 80333 Munich, Germany
}

Submitted: 29 October 2018 | Accepted: 13 March 2019 | Published: 28 March 2019

\begin{abstract}
The EU's energy transition has advanced rapidly over the last decade, with important implications for the policy landscape. Scholars have characterized the Emissions Trading System (ETS) and the Renewable Energy Directive as the most important policies for reducing greenhouse gas emissions in the electricity sector. However, since the early 2010s, non-governmental and industrial actors have debated whether renewable energy (RE) support and targets are compatible with the ETS. This article systematically assesses the policy preferences of five groups of non-governmental actors with respect to the role of the ETS versus RE policies in three policy processes. For most groups, preferences remain stable across the policy processes. In the electricity industry group, preferences vary from one policy process to another. During the ETS-reform, this group of actors argues that the ETS should be the main climate policy, whereas, in the Clean Energy Package-process, almost half of the utilities endorse continued RE support. This represents a shift in their line of reasoning and policy position: from asserting that RE policies 'destroy' the ETS, towards a position which recognizes the value of having both the ETS and RE policies as complementary instruments in the policy mix. The findings point to increasing support for RE policies, which is important for policy makers and scholars involved in designing and implementing the EU's decarbonization policies.
\end{abstract}

\section{Keywords}

emissions trading system; energy policy; energy transition; European Union; policy mix; renewables

\section{Issue}

This article is part of the issue "EU Energy Policy: Towards a Clean Energy Transition?", edited by Dag Harald Claes and Kacper Szulecki (University of Oslo, Norway).

(C) 2019 by the author; licensee Cogitatio (Lisbon, Portugal). This article is licensed under a Creative Commons Attribution 4.0 International License (CC BY).

\section{Introduction}

The need for deep reductions in global Greenhouse Gas (GHG) emissions is urgent and tremendous (IPCC, 2018). Confronted with recent evidence from climate scientists, the European Commission (hereafter: Commission) has called for accelerating decarbonization endeavors in the EU, targeting climate-neutrality by 2050 (Commission, 2018a). This has major implications for decarbonization policies in the EU. Given the key role of the electricity sector for reducing GHG emissions, this article takes a closer look at two policies that have been characterized as 'the key policy' for decarbonizing the electricity sector by different types of actors: the Emissions Trading System (ETS) and the Renewable Energy Directive (RED).

Renewable energy (RE) policies and the ETS are both policies whose ultimate objective is to reduce GHG emissions. However, these two policies follow different logics: the former provides financial support and market advantages for specific low-carbon technologies, whereas the latter leaves it to market-mechanisms to decide where emission reductions should take place and through which technologies they should occur. Since they co-exist in the European electricity sector, it is important to study how they work in relation to each other. Scholars have pointed to the need for analyzing policy instruments in their mix and encourage researchers to take a policy-mix perspective (Flanagan, Uyarra, \& Laranja, 2011; Rogge \& Reichardt, 2016).

Since the adoption of the EU's 2020 Climate and Energy Package, there has been much debate regarding what the EU's policy mix should look like. Scholars have argued that this discussion can be described as a conflict between different logics in climate policy, i.e. 
whether to pursue a 'technology-neutrality approach' or a 'technology development approach' (Boasson \& Wettestad, 2013; Fitch-Roy, 2017). These two opposing perspectives are reflected in different strands of literature. Economists have argued that carbon pricing is superior to other policies in terms of cost-efficiency (Fischer \& Newell, 2008) and that this instrument should be able to work alone without other measures in the policy mix (Böhringer \& Rosendahl, 2010). On the other hand, innovation scholars argue that in order to successfully combat climate change, innovation in all its forms will be indispensable (Fagerberg, 2017). This includes not only technological innovation but also new modes of consumption and of organizing social systems. Hence, it is increasingly recognized that we need a multiplicity of instruments to foster transitions (Rogge, Kern, \& Howlett, 2017). One important insight from this literature is the value of creating niches in order to help the uptake of new and more sustainable technologies. Even though this might be costly in the beginning, it might trigger rapid cost reductions as has been experienced with wind and solar power. The literature on 'strategic niche management' (Kemp, Schot, \& Hoogma, 1998) elaborates on the elements of successful niche building and identifies market protection as one key factor together with networking and learning. The EU's RE directive from 2009 contains several of these elements through its binding RE targets on member state (MS) level, RE action plans, and enabling RE support schemes.

Despite the salient debate on the relationship between the ETS and RE policies, the policy processes around these two types of policies have not been sufficiently explored in the literature, with Boasson and Wettestad (2013) and Fitch-Roy (2017) being noteworthy exceptions. This article examines the policy preferences of five groups of non-state actors with respect to the role of the ETS versus RE policies in recent policy processes. It systematically assesses the positions of industry, electricity producers, traders, RE associations, and environmental NGOs (E-NGOs) across three distinct policy processes through an extensive review of consultation responses combined with a limited number of in-depth interviews. It seeks to understand the different strategies taken by these groups of actors and asks:

RQ: Why do different actors hold substantially different policy preferences towards the ETS and RE support-and are preferences consistent across policy processes?

A particular look at the policy preferences of these actors is highly relevant for analyzing the unfolding transition in the electricity sector, given that many of them are intimately involved in-and affected by-the actual changes. Previous studies have shown how the positions of particular groups of actors have influenced policy outcomes through successful lobbying strategies (Gullberg, 2013; Ydersbond, 2014). Since the energy transition is an ongoing process, it is valuable to capture the policy preferences at different stages in order to analyze how the transition affects the involved actors and vice versa. Moreover, assessing policy preferences helps to identify main battle lines in the policy process and informs on feasibility for future policy outcomes. In light of ambitious climate targets and the need for climate action, the analysis provides useful insights for policymakers and scholars about policy mix designs in advancing transitions.

For most actors, I find that preferences remain stable across the policy processes. Industry associations favor a weak ETS and elimination of RE policies. E-NGOs and RE associations argue that both policies can and should coexist in the policy mix. For the electricity industry, preferences vary between processes. During the ETS-reform, this group advocated that the ETS should be the main climate policy, whereas, in the policy process around the Clean Energy Package (CEP), almost half of the actors in my sample argue that we still need RE support. In other words, the policy preferences with respect to these two policies are apparently inconsistent across policy processes. I suggest that the main explanation for this can be found in organizational factors that have resulted in a shift in business strategy. Confronted with changing legal frameworks, alarming climate science, consumer demands, and higher climate risks, these companies have responded by increasingly investing in RE. They have established RE departments and spelled out strategies for increasing RE deployment. However, along with augmented RE portfolios, they recognize that the ETS might not be sufficient to enable RE investments and, hence, shift their preference in favor of continued RE policies.

The article is structured as follows: Section 2 gives a brief introduction of the ETS and RE policy in the EU with a focus on recent developments. Section 3 introduces the theoretical perspectives from the policy mix literature and key expectations based on assumptions from rational choice institutionalism. Section 4 explains the methods applied, followed by the results in section 5 . Section 6 concludes.

\section{Theoretical Framework}

\subsection{Policy Mixes and Their Characteristics}

Various strands of literature have explored important aspects of policy mixes from different angles (Edmondson, Kern, \& Rogge, 2018). In addition to the traditional study of policy strategies and instruments, recent contributions have highlighted the role of the policy process in policy mixes (Flanagan et al., 2011). Rogge and Reichardt (2016) thus propose treating the policy process as a distinct building block when analyzing policy mixes. They argue that policy processes cover all stages of the policy cycle, including "problem identification, agenda setting, policy formulation, legitimization and adoption, implementation, evaluation or assessment, policy adaptation, succession and termination" (p. 1625). 
The public policy literature has focused on assessing how different policies, including their policy strategies and policy instruments, affect each other in a policy mix. This has been termed policy interaction. Different frameworks have been developed to assess the success of policy mixes (Del Río, 2014; Howlett \& Rayner, 2007; Rogge $\&$ Reichardt, 2016). These contributions suggest various assessment criteria for evaluating interactions and identify consistency and coherence as key characteristics ${ }^{1}$. Consistency refers to how well the elements in the mix work together with respect to achieving the policy objectives. It incorporates both the absence of conflict as well as synergistic effects. Coherence describes how well the policy processes of different fields are aligned. It can also refer to the capacity of institutions and policymakers to implement specific outcomes, which is less relevant for this article.

Policy interaction in policy mixes takes place on several levels. (Flanagan et al., 2011; Rogge \& Reichardt, 2016). There can be interaction between policy elements, i.e. between instruments, between strategies and instruments or between different policy strategies within the same (or overlapping) policy fields. Another type of interaction is between policy processes, in which negotiations or lobby activities in one process influence the events in parallel processes. One example of this is what Boasson and Wettestad $(2013$, p. 37) term 'bargained interaction', which summarizes the observation made by Liberal Intergovernmentalism that policymakers may initiate policy linkages in bargaining situations in order to enhance their impact during the policy processes (Moravcsik, 1998).

For the study of policy interactions between the ETS and RE policies at the instrument level, economists have performed econometric analyses to quantify these effects. Within neoclassical economics, it is a widely held tenet that RE subsidy schemes have "no effect on total carbon emissions at all if the electricity industry is also subject to a cap-and-trade system" (Jarke \& Perino, 2017 , p. 103). Studies based on theoretical economic modeling find that such a policy mix can even lead to increased emissions (Böhringer \& Rosendahl, 2010). Moreover, the combination of these policies will increase mitigation costs (Fankhauser, Hepburn, \& Park, 2010). In order words, the policies are inconsistent. As a result, economists have recommended to modify the policy design of the trading scheme so that such negative effects can be reduced (e.g., Goulder, 2013).

The general perception of the economists contrasts with the insights derived from innovation studies. Innovation scholars have emphasized the need to help new and immature technologies. They established the concept of a 'technological regime' to explain why it is so difficult for new actors and technologies to compete with established actors (Nelson \& Winter, 1977). The regime consists not only of technologies but the whole system built around it. This is why innovation scholars have emphasized the role of niches in protecting and nurturing new and sustainable technologies (Kemp et al., 1998; Smith \& Raven, 2012). Insights from this literature identify three processes as crucial for niche development: learning, network building, and the articulation of expectations (Geels, 2011). Hence, the task of niche management is not only to provide financial support but also to help new technologies overcome the barriers to entering the market. Since new players meet numerous obstacles when competing with established technologies in the market, support for sustainability transitions must be more than simply financial support as new technologies will require institutional and social change (Kemp, 2011, p. 16). Innovation scholars have therefore argued that green energy technologies require specific support policies (Kemp, 2011, p. 16) and that carbon pricing "should be seen as a supplement to innovation policy, not an alternative" (Fagerberg, 2017, p. 3). The RED (2009/28/EC) is a typical example of niche protection, in which the new technologies are shielded from market exposure. In addition to national support schemes, it provides producers of renewable electricity certain advantages (priority dispatch and free grid connection). However, the innovation literature also argues that support to niche technologies becomes superfluous as market penetration increases (Hellsmark \& Söderholm, 2017; Rogers, 1996). Therefore, policymakers and researchers should closely monitor the situation to identify the point at which RE producers are able to invest in new power plants without support.

\subsection{Analyzing Policy Preferences}

Building on recent policy mix literature (Lindberg, Markard, \& Andersen, 2018; Rogge \& Reichardt, 2016), this article includes the policy process into the policy mix analysis and takes a particular look at the policy preferences of key non-governmental actors. Policy preferences are conceptualized as the positions taken, and expressed publicly, by actors regarding specific policy problems. Scharpf (2000) uses the notion 'actor orientation' for actor preferences and perceptions, and suggests treating these orientations as a theoretically distinct category. Different theoretical approaches depart in their views on what shapes policy preferences. Sociological and historical institutionalism stresses how policy preferences are socially constructed and shaped by institutional norms and practices (Berger \& Luckmann, 1966; March \& Olsen, 1989).

Policy preferences are neither clear nor stable. They develop over time. They are shaped not only by forces exogenous to politics and decision making but also by

\footnotetext{
${ }^{1}$ Del Rio (2014) uses the terms conflicts, complementarities, and synergies, put points out that there is no consensus on these definitions in the literature on interaction (p. 273). Del Rio also distinguishes between assessment criteria for the policy mix and instrument interaction, although this paper does not engage with this discussion.
} 
the processes of politics themselves. (March \& Olsen, 1989, p. 146)

The literature on institutional theory distinguishes between institutional pressure (external drivers) and organizational factors (internal drivers) for preference and strategy formation. The former includes market external drivers (customer/investor demands and competitive pressure) and non-market external drivers (regulatory framework, media and civil society pressure) whereas the latter are organizational level (firm characteristics like type and size, internal communication and organizational inertia) and individual-level psychological drivers among leaders and individuals within the organization (Delmas \& Toffel, 2008). They have shown that institutional pressure will affect organizations differently, depending on their organizational characteristics such as ownership structure, trust, and identity. As a result, scholars have recognized that institutional factors alone cannot explain the differences between firms regarding their business and marketing strategy (e.g., Delmas \& Burbano, 2011).

Another possibility for a change in publicly expressed preferences is that the change does not represent real action, but a shift in how the actors present themselves as a part of their market strategies, also called 'selective disclosure' or 'greenwashing'2. Many of the drivers for such activity overlap with those listed above (Delmas \& Burbano, 2011).

Rational choice theory, on the other hand, assumes that actors have stable preferences directed at optimizing their self-interest and exogenous preference formation (Hall \& Taylor, 1996; Scharpf, 2000). Typically, rational choice institutionalists start out by assessing the preferences of actors in order to explain the emergence of institutions, whereas historical institutionalists focus on how institutions influence individuals' behavior (Thelen, 1999, p. 397). In a strong rational choice perspective, preferences are unrelated to the environment in which they are generated. Although many economists accept that this is a weak assumption, they acknowledge that it enables preferences to be incorporated into econometric models (Guillen-Royo, 2007). Sharp argues that the methodological advantage of the rational choice approach for political scientists is that it enables the formulation of working hypotheses based on findings in existing literature. Assuming that key preferences remain stable allows us to set up initial expectations about the population in the sample. This procedure simplifies the identification of the outliers, which subsequently serves as the research puzzle (Scharpf, 2000; Thelen, 1999).

Drawing on the assumptions set out in rational choice theory, I expect actor preferences to be stable across policy processes which take place in parallel and over a limited time period. I also expect policy prefer- ences to align with the positions of the same types of actors that are documented in the literature. As a result, my expectation is that industry and electricity producers will have a strong preference for the ETS and mobilize arguments from the literature on economics, i.e. arguing that the ETS and RE support is inconsistent and should not co-exist in the policy mix. I expect that RE industry and E-NGOs will favor a broad set of policies that should co-exist with the ETS and give priority to measures which promote technology development, as encouraged by the innovations studies literature.

\subsection{Analytical Framework}

The article structurally assesses and compares the policy preferences of key non-governmental actors in three policy processes. Figure 1 illustrates that there is policy interaction on all levels of these distinct processes, i.e. between policy strategies, between instruments, between strategies and instruments, and between policy preferences. The scope of this study is the policy preferences for the ETS and RE policies and the interaction of preferences. My operationalization of policy interaction is two-fold: First, I assess whether actors perceive policies as consistent and coherent, second, I assess whether actors' preferences are consistent across the respective policy processes.

The three policy processes are listed in Table 1 and include the ETS reform, the process preceding the adoption of the 2030 Energy and Climate Framework and the Clean Energy Package for all Europeans, for which I assess consultation responses for the Renewable Energy and Electricity Market Directive.

The reason why I include the policy process on the Electricity Market Directive in C) is because this directive is highly important for future RE deployment. Along with increasing shares of RE in the electricity market, market designs and regulations need to be adjusted. Issues such as system operation, trading rules, and grid development have major implications for RE, and many of the changes in the recast directive address these issues. As a result, most actors express their positions on RE versus the ETS in the associated consultation responses.

\section{EU Climate and RE Policy}

Multiple climate policies have co-existed in the EU since the early 2000s. The ETS and RE policies developed in parallel during the 1990 s, leading to distinct directives which regulate the ETS and RE deployment. The directives have co-existed since the implementation of the ETS in 2005. The EU has repeatedly referred to the ETS as being the cornerstone or flagship of its climate policy (Wettestad \& Jevnaker, 2016). However, scholars have argued that it is RE policies which have been key for driving the en-

\footnotetext{
2 Selective disclosure is defined by Marquis, Toffel, and Zhou (2016) as a strategy to gain or maintain legitimacy by disproportionately revealing beneficial performance indicators to obscure their less impressive overall performance. This is similar to the concept of greenwashing, which has been described as disinformation disseminated by an organization so as to present an environmentally responsible image (Vos, 2009).
} 


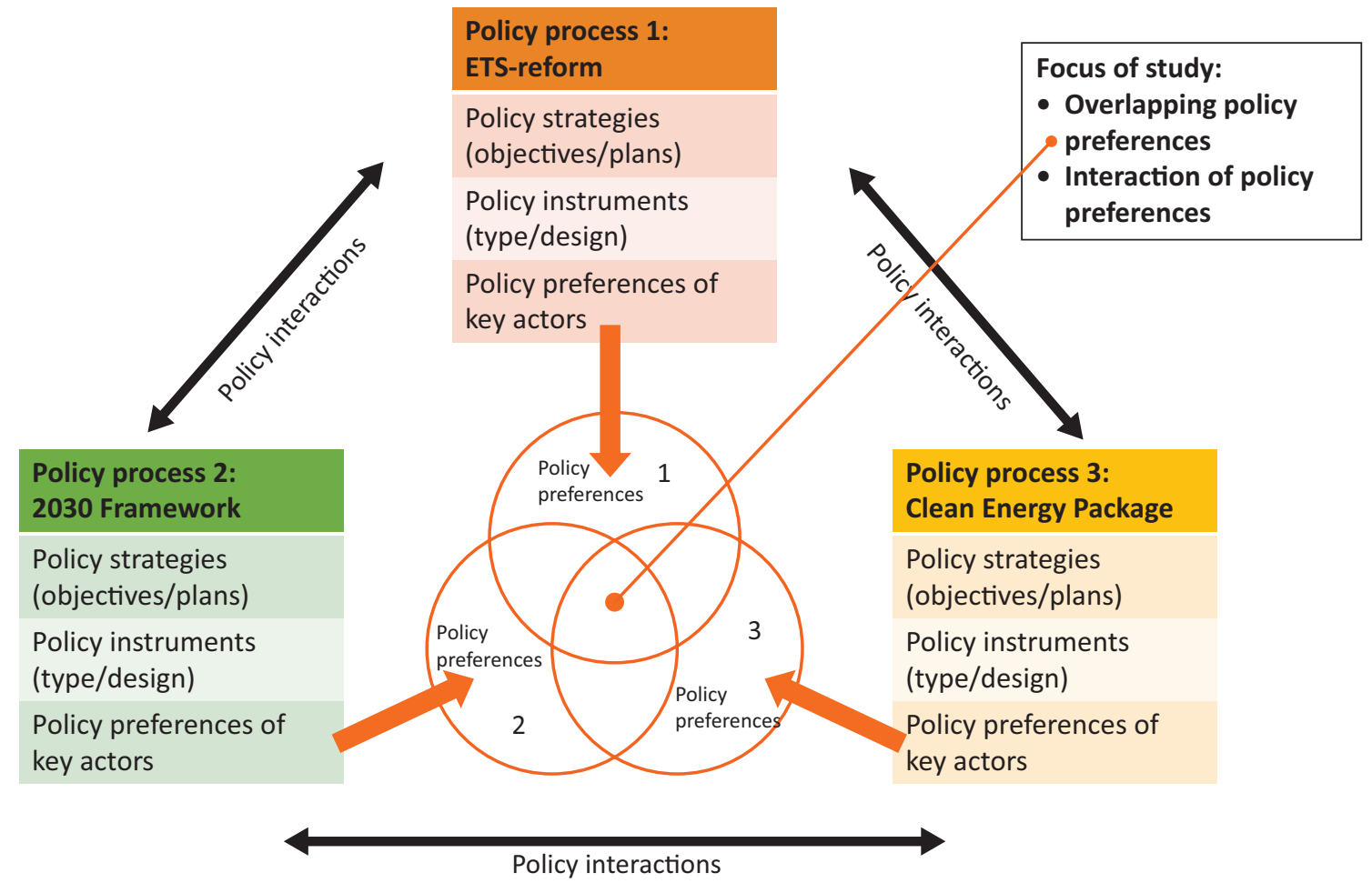

Figure 1. Analytical framework.

Table 1. Policy processes assessed in the article.

\section{1: ETS reform}

\section{2: 2030 Energy and} Climate Framework

2013-2014

Targets for 2030:

40\% GHG emissions reduction

$27 \%$ RE $27 \%$ (at least) increase in energy efficiency
3: Clean Energy Package: RED

Electricity Market Directive (EMD)

2015-2018

Key policy strategies and instruments

Reduce GHG emission in sectors covered by the scheme (industry and electricity production) Emissions reduction targets:

$43 \%$ by 2030 (to 2005 )

$21 \%$ by 2020 (to 2005 )
RED: Facilitate and enable RE deployment Binding national RE targets National Renewable Energy Action Plans (NREAPs)

EMD: Ensure affordable, reliable and sustainable electricity production in the EU Establish internal market for electricity; promote/facilitate cross-border trade ergy transition so far (Cointe \& Nadaï, 2018). The following sub-sections provide brief overviews of the development of the ETS and RE policies until 2018.

\subsection{EU-ETS: The Climate Policy Flagship}

Climate policy in the EU gained momentum after the signing of the Kyoto Protocol (KP) in 1997. Following failed attempts to introduce a carbon tax in the early 1990s, the EU tried to prevent a KP based on flexible mechanisms (Boasson \& Wettestad, 2013). Still, this ended up being a key feature of the KP, above all due to the US, who made their acceptance of the KP conditional upon the inclusion of emissions trading. The Commission revisited the idea of emission trading and presented its first proposal for an ETS in 2001 (Commission, 2001). In 2003, the directive establishing the ETS (2003/87/EC) was adopted. For a review of this process, see Meckling (2011). The ETS was organized into different consecutive periods (phases) that would allow for a regular revision of the system. As of 2018, it covers energy-intensive industries and large electricity and heat producers in 31 countries.

Phase I (2005-2007) was a test phase to prepare for phase II (2008-2012). In these first phases, almost all allowances were allocated to the industry for free (minimum 95\% in phase I, decreasing to $90 \%$ in phase II). The economic crisis in 2008-2009 resulted in decreasing emissions, causing a large surplus in emissions allowances. This was carried over into phase III (2013-2020), in which 58\% of allowances are auctioned. Even though this was a substantial increase compared to phase II, the issue of free allocation (to industries fac- 
ing a high risk of carbon leakage or electricity producers in east-European countries) is contested, as shown in Section 5.1.

The large surplus and plunging $\mathrm{CO}_{2}$ price spurred the reform process of the ETS, which led to substantial changes in the policy. The reforms started with backloading of in total 900 million allowances in the period 2014-2016 and the adoption of a Market Stability Reserve (MSR) in 2015 (European Parliament and Council, 2015). This ensures that backloaded allowances are transferred to the reserve, instead of being auctioned in the market in 2019-2020, as initially agreed. The purpose of the MSR is to manage the number of allowances in circulation at any given time. In 2018, a revised ETS directive was adopted (Directive (EU) 2018/410) which doubles the intake of allowances into the MSR, prescribes permanent cancellation of surplus allowances in $2023^{3}$, and strengthens the linear reduction factor from the current $1.74 \%$ to $2.2 \%$. For parts of the industry that are less exposed to carbon leakage, free allocations will be phased out by 2030 (Commission, 2018b). In their account of the reform process until 2015, Wettestad and Jevnaker (2016) characterized the ETS reform as 'rather successful'. Early summer 2018, the $\mathrm{CO}_{2}$ price climbed from sustained low levels of around $€ 4-6$ to $€ 20$ (Montelnews, 2018).

\subsection{RE Policy: Targets and Technology Development}

The EU started discussions about promoting RE deployment already in the late 1980s (Boasson \& Wettestad, 2013). The first RED (2001/77/EC) was adopted in 2001 (Fouquet \& Johansson, 2008). Most importantly, it set out a joint RE target (minimum $12 \%$ by 2010) and indicative targets for renewable electricity (amounting to $21 \%$ of gross electricity consumption). A recast RED (2009/28/EC) was adopted in 2009 after strong negotiations (Skjærseth, Eikeland, Gulbrandsen, \& Jevnaker, 2016). Main policy elements was a $20 \%$ target for the EU, binding national targets for all $28 \mathrm{MSs}$ and National RE Action Plans. This provided the Commission with considerable possibilities to control and redirect national policies. The RED (2009/28/EC) also made important provisions on the design of support measures, grid rules, and administrative procedures in relation to RE.

In 2015, the Commission started the work with the 'Clean Energy Package for all Europeans', including a recast RED for the period 2021-2030. Adopted in 2018, it sets out a joint $32 \%$ target for 2030 , but no binding targets on MS level. It allows continued financial support for RE and makes important restrictions on their design ${ }^{4}$. The rules regulating dispatch and grid access are moved to the Electricity Market Directive.
In addition to the RED, the EU regulates renewable energy support through the Guidelines on State Aid for Environmental Protection and Energy (SAG). In the guidelines for the period 2014-2020, the Commission states its strategy to phase out renewable energy subsidies between 2020 and 2030 (Commission, 2014). The official strategy of the Commission, the European Council, and the European Parliament is to let the energy market be the main tool to "allow for the integration and development of larger volumes of electricity produced from renewable sources" (Commission, 2016).

\subsection{Policy Interaction}

The EU's energy and climate policy since 2010 has been characterized by the question of whether there should be one single policy (the ETS) with one single target (for GHG reduction), or whether this should be combined with distinct policies and targets for RE and energy efficiency. The arguments used in the policy processes coincide largely with contrasting theoretical positions described above. Fitch-Roy (2017) argues that the overlap of the 2030 Energy and Climate Framework and the ETSreform resulted in a weak RE target, for two reasons. First, many actors invested considerable resources into the ETS-process, limiting their capacity to engage wholeheartedly in the 2030 debate (p. 249). Second, for some actors, it became logically inconsistent to support RE targets while making the case that the ETS should be the primary driver of climate and energy policy (p. 260). The latter is an example of how policy preferences within distinct policy processes interact. Interestingly, this interaction between policy preferences is not observed in the policy processes preceding the ETS and RE directives adopted in 2009. Boasson and Wettestad (2013) found that all major European electricity producers strongly favored a market-based instrument within the RE directive $^{5}$, but that they didn't use the negative interaction between the RE policies and the ETS as an argument against the RED.

\section{Methods}

Key interest actors and organizations were identified by means of an expert group consisting of seven experts, who were asked to rank the most influential actors in EU electricity policy. The ranking was based on a preselection which was made based on which actors had submitted a consultation response to the consultations in the CEP-process. The experts were researchers or industry actors working on or within the field. A few actors were removed from the sample because they had not been active in the policy process on the ETS, which

\footnotetext{
3 "From 2023 allowances held in the reserve above the total number of allowances auctioned during the previous year should no longer be valid" (recital 23, Directive (EU) 2018/410).

4 "Support schemes...shall incentivize integration of RE sources in the electricity market in a market-based and market-responsive way, avoiding unnecessary distortions of electricity markets...and ensure that RE producers are responding to market price signals" (Renewable Energy Directive (2018) Art 4.1-2).

${ }^{5}$ With the exception of Iberdrola.
} 
attracted a much larger audience than the electricity sector. In the end, I chose to add three utilities to the sample because they were mentioned as being influential by the interviewees. After sorting the actors according to the type of actor, I removed actors who were not part of an appropriate group. I ended up with a list of 30 actors and five groups of actors Table 2. Please note that I use the current names of actors who changed their name during the period ( $\varnothing$ rsted, WindEurope, and SolarPowerEurope).

To capture the policy preferences in different policy processes, I assessed their consultation responses to the Commission. A list of the consultations assessed for each policy process is included in the Annex.

To identify and compare the policy preferences, I created a coding scheme. I arrived at three main coding dimensions and several sub-dimensions (Table 3 ). The coding questions were developed bottom-up from the data and were based on insights in the literature in order to identify the main distinctions between actors. The first coding dimension (D1) captures the policy mix preference and assesses the actors' preferences regarding the ETS as a main climate policy (SD1.1) and RE support (SD1.2). The second dimension (D2) assesses the preference for reforming the ETS, and dimension three (D3) assesses what I call 'Renewable Energy Ambition'. The SD1.1 is assessed twice, initially in the ETS consultations and subsequently in the CEP-consultations. Values for SD1.2 and D3 are derived from the CEP, whereas D2 is based on ETS consultation documents.

The coding of consultation documents was carried out in Nvivo and Excel. Each consultation document was coded with specific values for the respective dimension on a scale from 1 to 4 . See Table $C$ in the annex for an explanation of each (sub-)dimension and the corresponding lead questions. In the end, the values from the subdimensions were added together to arrive at one single actor value for each main dimension.

In order to explore different explanations for my findings, I carried out seven semi-structured interviews with some of the actors in the sample. The interviews were carried out in the period November 2017-January 2019. The list of interviews can be found in the annex (Table A). One obvious limitation of the study is that it does not include the positions of governments and EU institutions. Therefore, the article does not embark on the task of explaining the policy outcomes that resulted from the policy processes assessed. A larger number of interviews would be needed to explore the drivers behind the policy preferences in greater detail.

\section{Results}

For most groups of actors, policy preferences remain stable across the policy processes that were assessed in this article. This is true for industry associations, renewable associations, E-NGOs and electricity traders. These groups have what I call consistent policy preferences. This is only partly the case for the electricity industry, where many actors express inconsistent preferences from one policy process to another. As postulated by rational choice institutionalism (Section 2.2) these deviant actors are the most interesting finding of the assessment. Section 5.2 thus focuses on presenting and explaining this finding.

Table 2. Key non-state actors in EU electricity policy.

\begin{tabular}{ll}
\hline Environmental NGOs & CAN, Greenpeace, WWF, E3G \\
\hline Renewable associations & BEE, EREF, WindEurope, SolarPowerEurope \\
\hline Electricity producers and their associations & EDF, Enel, Iberdrola, RWE, Statkraft, Total, Vattenfall, Fortum, E.on, $\varnothing$ rsted, \\
& CEZ, CEDEC, Eurelectric, Foratom, Euroheat and power \\
\hline Traders & Europex, EFET \\
\hline Industry associations & BusinessEurope, CEFIC, IFIEC, Euracoal, Eurochambers \\
\hline
\end{tabular}

Table 3. Coding dimensions for capturing policy preferences in the consultation processes.

\begin{tabular}{ll}
\hline Main dimension & Sub-dimensions \\
\hline D1) Instrument Mix for the Energy Transition & SD1.1 The role of the ETS \\
& SD1.2 RE support \\
\hline D2) ETS Ambition & SD2.1 Removal of allowances surplus and tightening of the LRF \\
& SD2.2 Free allocation of $\mathrm{CO}_{2}$ allowances post2020 \\
\hline D3) Renewable Energy Ambition & SD3.1 RE deployment \\
& SD3.2 RE potential \\
& SD3.3 RE targets \\
& SD3.4 RE leads to increased system costs \\
\hline
\end{tabular}




\subsection{Policy Preferences}

Figures 2-4 and Table 4 show the findings of the analysis. The E-NGOs and the RE associations hold largely the same positions across the three policy processes. As a result, these two groups of actors are merged into a 'policy preference group A'. Their preferences are characterized by very high RE ambitions, a univocal call for high and binding targets for RE and GHG emissions reduction and a strong preference for continued RE support. As for the ETS, they call for a strengthening of the scheme through rapid and thorough ETS reform. Moreover, they do not believe that there is a need for free allocation of allowances to any actors. Regarding the relationship between ETS and RE policies, they explicitly argue that the ETS must be complemented by additional policies:

WWF warns strongly against a carbon market 'orthodoxy' where the Commission would perpetuate the notion that the EU ETS can deliver all the needed emission reductions in a timely manner on its own. No single policy instrument can be left alone to achieve this complex and multi-faceted task since it cannot correct all the relevant market failures....In particular, the EU ETS must be framed as having its rightful place in an optimal mix of policy instruments in the pre and post 2020 context. (WWF, ETS 2015, 6.2)

ETS alone has not been and will never be capable of ensuring meaningful reductions of greenhouse gas emissions. (Solar Power Europe, ETS 2015, 6.4)

These arguments contrast the positions of industry associations, traders and almost the entire electricity industry in the ETS process. These three groups insist that the ETS should be the 'key', 'main', or 'only' climate policy of the EU. Many actors highlight the detrimental effect of RE policies on the ETS and the inefficiency of the current policy mix. Most of the electricity industry and the traders (merged into 'policy preference group $\mathrm{B}^{\prime}$ in Figure 2) advocate a strengthening of the ETS, with some variation as to how much and how rapid this should happen. The industry group (C) and RWE do not see a need to reform the ETS. They argue that the ETS is functioning and delivering its objective, i.e. GHG emission reductions in the sectors covered by the scheme. TOTAL stands out from all groups with inconsistent preferences in their ETS-submissions in 2013 and 2015 about whether the ETS should be the main tool, combined with a preference for not strengthening the scheme.

POLICY PROCESS 1: ETS REFORM - Consultation responses 2013 / 2014 / 2015

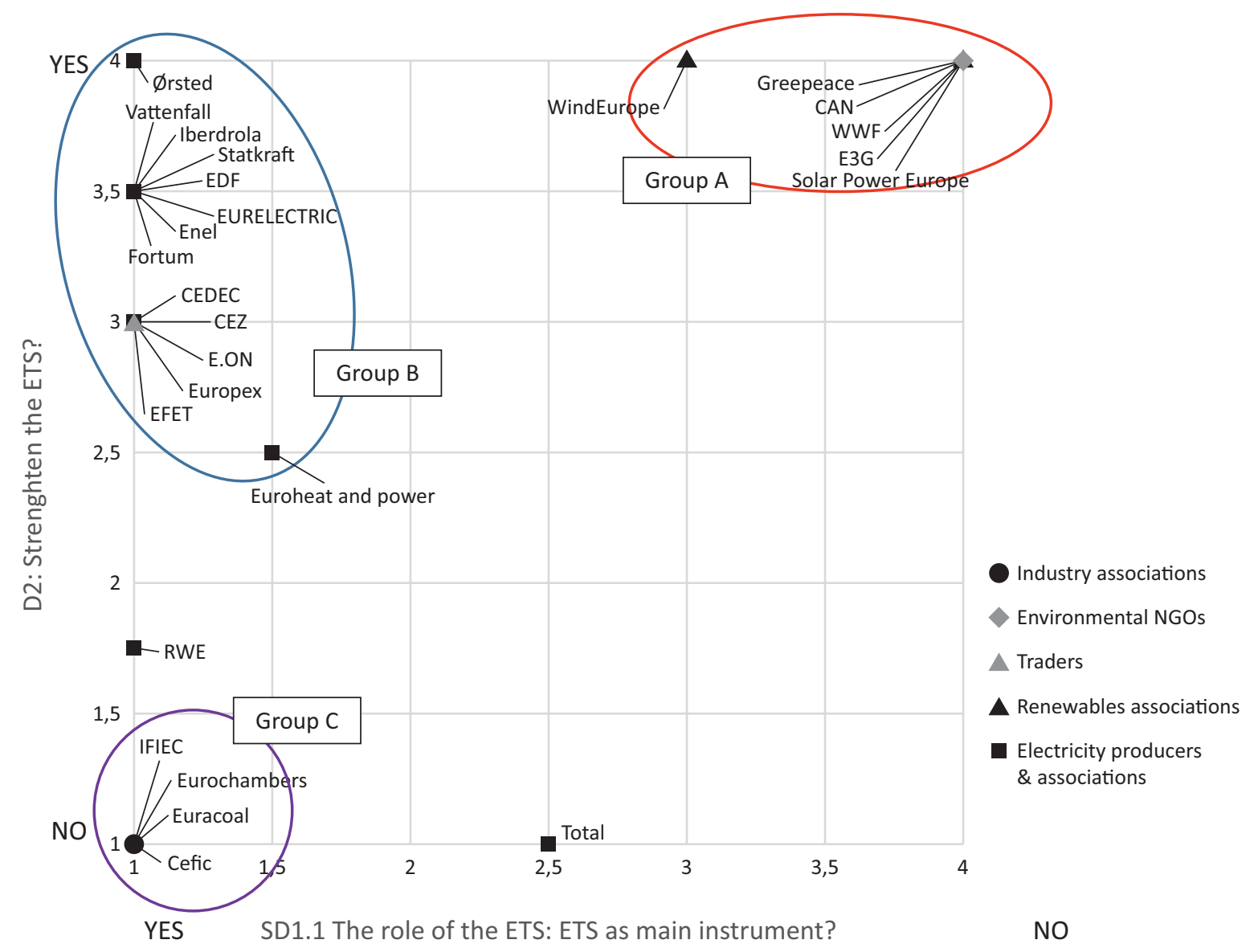

Figure 2. Policy preferences as expressed in consultation responses regarding the ETS reform. 
Table 4. Overview of policy preferences for GHG and RE targets in the 2030 Energy and Climate Framework. Sources: Consultation responses 2030 Framework; Ydersbond (2016).

\section{POLICY PROCESS 2: 2030 Framework-Consultation responses 2013}

\begin{tabular}{|c|c|c|c|c|}
\hline Actor type & $\begin{array}{l}\text { Policy } \\
\text { Preference } \\
\text { Group }\end{array}$ & Actor & $\begin{array}{l}\text { GHG reduction } \\
\text { target? }\end{array}$ & RE target? \\
\hline \multirow[t]{4}{*}{ Environmental NGOs } & \multirow{7}{*}{$A$} & CAN & $55 \%$ & At least $45 \%$, binding on national level \\
\hline & & WWF & $55 \%$ & At least $45 \%$, binding on national level \\
\hline & & Greenpeace & $55 \%$ & At least $45 \%$, binding on national level \\
\hline & & E3G & $55 \%$ & At least $45 \%$, binding on national level \\
\hline \multirow{3}{*}{$\begin{array}{l}\text { Renewables } \\
\text { associations }\end{array}$} & & EREF & $40 \%$ & At least $45 \%$, binding on national level \\
\hline & & SolarPowerEurope & $40 \%$ & At least $45 \%$, binding on national level \\
\hline & & EWEA & $40 \%$ & At least $45 \%$, binding on national level \\
\hline \multirow{14}{*}{$\begin{array}{l}\text { Electricity producers } \\
\text { and their } \\
\text { associations }\end{array}$} & \multirow{7}{*}{ B } & Eurelectric & At least $40 \%$ & $27 \%$, binding, but not on national level \\
\hline & & Foratom & $40 \%$ & no \\
\hline & & EDF & Single binding & no \\
\hline & & Statkraft & At least $40 \%$ & no \\
\hline & & CEZ & Single binding & no \\
\hline & & RWE & Single binding & no \\
\hline & & Fortum & Single binding & no \\
\hline & \multirow[t]{7}{*}{$B / D$} & $\varnothing$ rsted & At least $40 \%$ & Binding target, also on national level \\
\hline & & TOTAL & $\begin{array}{l}\text { Consistent with } \\
\text { other major } \\
\text { emitters }\end{array}$ & No fixed target/Indicative target \\
\hline & & CEDEC & Legally binding & Binding target, also on national level \\
\hline & & Vattenfall & Single binding & no \\
\hline & & Iberdrola & Single binding & no \\
\hline & & E.on & Single binding & no \\
\hline & & ENEL & Single binding & no \\
\hline Traders & B & EFET & Single binding & no \\
\hline \multirow[t]{5}{*}{$\begin{array}{l}\text { Industry } \\
\text { associations }\end{array}$} & \multirow{5}{*}{$C(B)$} & CEFIC & $\begin{array}{l}\text { Dependent on } \\
\text { global agreement }\end{array}$ & no \\
\hline & & IFIEC & $\begin{array}{l}\text { Dependent on } \\
\text { global agreement }\end{array}$ & no \\
\hline & & Euracoal & $\begin{array}{l}\text { Dependent on } \\
\text { global agreement }\end{array}$ & no \\
\hline & & BusinessEurope & $\begin{array}{l}\text { Dependent on } \\
\text { global agreement }\end{array}$ & no \\
\hline & & Eurochambers & $\begin{array}{l}\text { Single binding, } \\
\text { taking the } \\
\text { outcome of } \\
\text { negotiations } \\
\text { into account }\end{array}$ & $\begin{array}{l}\text { Demand impact assessment of } \\
\text { inconsistencies. Consider relative } \\
\text { target. }\end{array}$ \\
\hline
\end{tabular}


The positions of the groups B and C in the ETSprocess are largely sustained in the 2030 Framework, where most of them lobby against a distinct RE target, with the exception of $\varnothing$ rsted, CEDEC, and Eurelectric (see Table 4). Ørsted's response contained elements from the 'technology development' logic (see Section 1) arguing that even though a strong ETS is fundamental for the green transition: "in itself, it is not sufficient to ensure volume, industrialization, and cost reductions and market maturity for next-generation RES technologies such as offshore wind" (DONG Energy, 2013). Eurelectric was initially against a separate RE target in their 2030 Framework-response but changed their position during 2014 to accept a modest target.

Whereas the ETS reform is characterized by clear divisions between the actors and rather 'extreme' positions, the CEP-process shows a more modest picture. Figures 3 and 4 show policy preferences as expressed in consultation responses to the CEP and distinguishes between showing the preference for RE support only (D1.2), and combining D1.2 with the ETS preference (D1.1) into a policy mix preference (D1).

The main division between the renewable industry and E-NGOs (group A) and industry associations (group C) is sustained. However, the electricity producers depart in their preferences for the ETS and RE support and form two separate policy preference groups: group B and D. When assessing the policy mix preference and not just RE support, the positions of the two groups $B$ and $D$ become even more distinct. Group B shows a strong preference for the ETS and argues that it should be the main driver for the energy transition in Europe. They propagate full integration of renewables into the market and that there should be no additional RE support or special advantages for mature technologies after 2020. Group D is characterized by higher RE ambitions and stronger preferences for RE support than group $B$. They also want a strengthening of the ETS, but many of them question whether this will be sufficient to ensure continued RE deployment. Some of them express specific preferences regarding how to ensure system reconfiguration in order to enable the integration of more RE into the system. This is a feature they share with actors in group A. An important difference between group $A$ and $D$ is that group $D$ actors express higher confidence in the ETS and its reform.

\subsection{Explaining Inconsistencies}

The assessment of consultation responses reveals the actors' official positions but does not provide much information about the motivations and drivers behind them. The 'puzzle' in my sample, i.e., the inconsistent prefer-

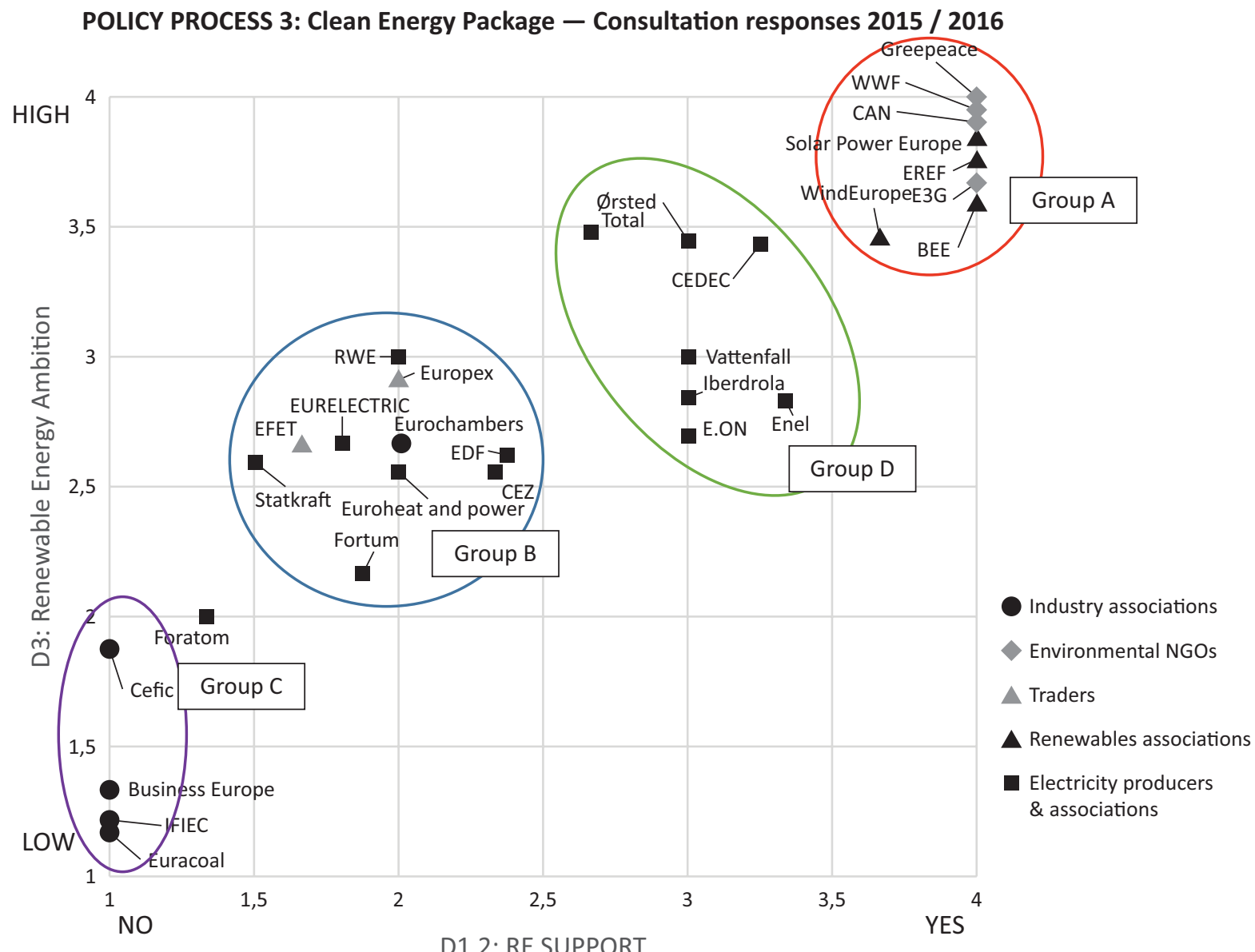

Figure 3. Policy preferences in the Clean Energy Package-process: RE ambition versus RE support. 
POLICY PROCESS 3: Clean Energy Package - Consultation responses 2015 / 2016

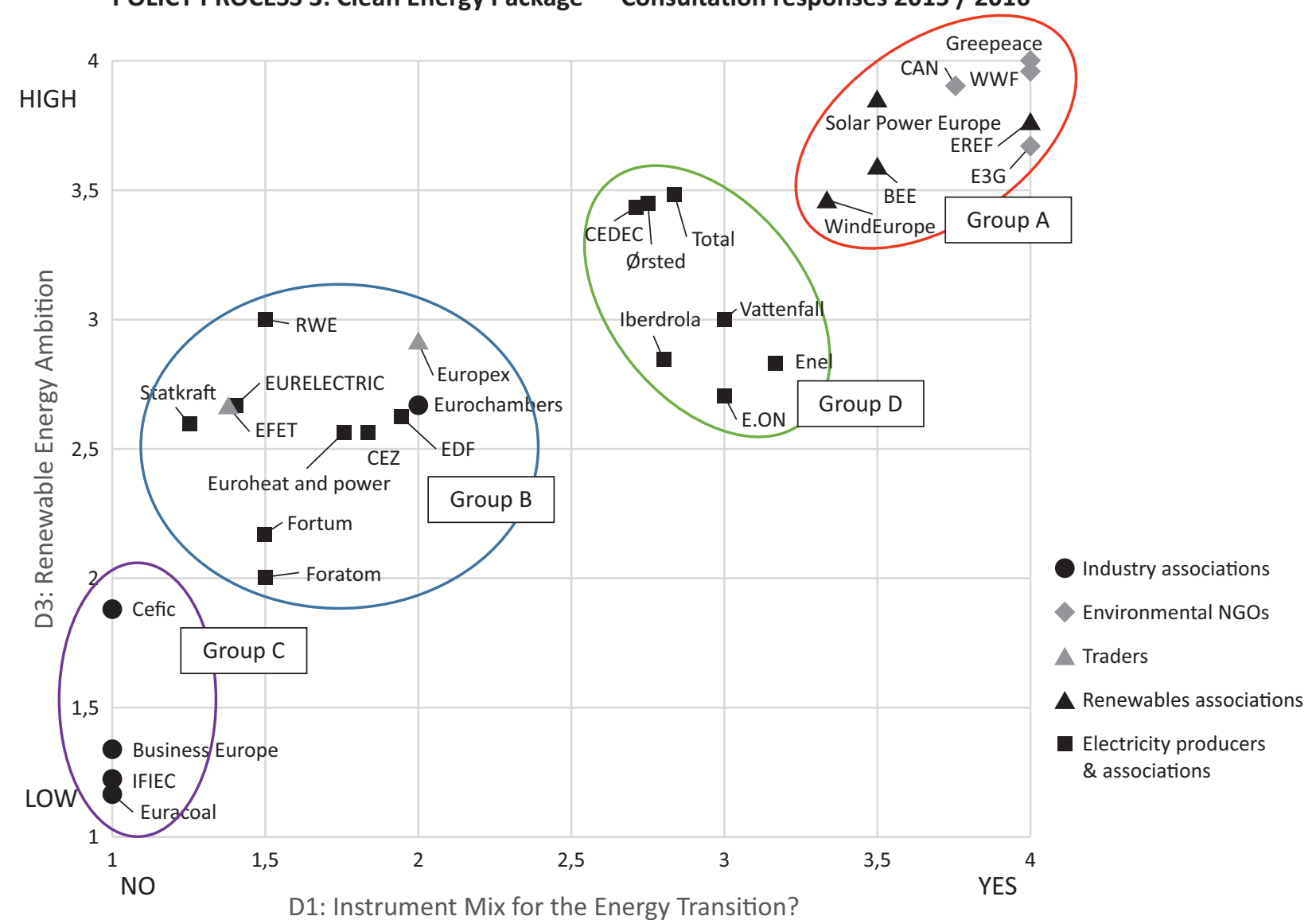

Figure 4. Policy preferences in the Clean Energy Package-process: RE ambition versus instrument mix.

ences across policy processes, is not yet documented or explored in the literature. Based on institutional theory literature and seven interviews with six actors from the respective groups (two in group $A$, two in group $B$, two in group D) and one electricity policy expert, I suggest the following explanations for the findings: 1) organizational factors, 2) institutional pressure and 3) reputation and market strategy. I will start with the first, which I argue is the most important.

Organizational factors include the characteristics of an organization, including size, type, internal structures, ethical values, and business model. For the electricity producers, their policy preferences vary with their production portfolios, which is linked to their economic interests. The 'pro-RE' utilities (group D) have shifted-or are in the process of shifting - their portfolios away from coal and are increasingly investing in RE. The interviewees (I5, 16) characterize this as a shift in business strategy and report that most of their investments are now in RE. One interviewee explains how this has resulted in a shift in policy preferences regarding the ETS and RE policies:

I would think that our company, ten years ago, maybe also five years ago, would probably have said that the ETS should be the main driver in the transformation, but as we have become increasingly active in building more and more renewables, I must say, it is not our position that we should stop with support schemes because the ETS is now strengthened. (I5)

Their preference for combining the two instruments is described as a consequence of the current situation in the market, where it is possible to build RE with no support at very favorable places, but that "in most cases, you still need support" (I5). 16 argues that their overall view is that ETS should be the main policy, but that they are "not so rigid and say that we do not need other policies as well". The companies are optimistic about technology development, they believe that RE will become even more competitive and that one will be able to deploy it without a support system in the future.

Group D actors share the view of group A to continue RE support, but the former is much more ETS-friendly and market-oriented. They express a strong belief in the ETS and argue that they want a general policy which adheres to market principles $(15,16)$. Regarding the inconsistencies in policy preferences, they explain that they pursue a two-track strategy in which they see both policies as complementary:

We would very much like the energy market to work and to be able to take investment decisions without 
subsidies. Whether and when it can happen is still unclear, but we don't want to say that it will never happen since we see that it does happen if certain things fall into place. (15)

Interestingly, 16 did not support a distinct RE target because they argue that there should be a balanced relationship between the GHG target and the RE target, i.e., you should not increase the RE target without increasing the GHG target too. 16 argues that RE support should target immature technologies and mentions offshore wind, which his company is investing in. He also points to other issues being more important for further deployment than support schemes, including grid development, balancing measures, and cross-border trade.

The positions of the 'pro-ETS' actors in the electricity industry (group B) who did not change their positions can also be explained by organizational factors and their business models in particular. Two interviewees argue that for utilities that are not carbon exposed, or even those whose portfolio is not exclusively coal-based, a higher carbon price will be profitable $(14,15)$. Since the price of fossil power production sets the price in the wholesale electricity market most of the time, all power producers (whose generation is dispatched) will experience higher prices when the carbon price increases. This is what researchers have called "indirect windfall profits" (Wrake, Burtraw, Lofgren, \& Zetterberg, 2012, p. 15). Confronted with decreasing wholesale electricity prices, the ETS is one of the few measures that can actually contribute to restoring these companies' revenue stream. This is supported by the study of Fitch-Roy, who finds that indirect windfall profits were a motivation for some of the utilities who lobbied for a strengthened ETS in the coalition 'Friends of the ETS' in the policy process for the ETS reform (Fitch-Roy, 2017, p. 259).

The recent reforms of the ETS were mentioned as dealing with many of the inconsistencies between the ETS and RE policies. However, one interviewee argues that fixing the inconsistencies through MSR and permanent cancellation of allowances was not the reason why the actors change their policy preferences towards RE policies. He believes the actors would have changed their position regarding RE policies anyway due to their business needs and that they would just have stopped talking about the inconsistencies (17).

Institutional pressure is another important part of the explanation. The interviewees lend particular weight to the importance of non-market institutional drivers such as the legal and regulatory framework and recent scientific findings regarding the urgency of climate change but also highlight market drivers such as consumer demand. Overall, the binding RE targets in the 2009 RE directive is characterized as an important driver for RE deployment in Europe and associated cost-reductions (I1, 13, 14). The RED as of 2009 amplified the dynamics that had started with national energy transitions in several front-runner countries (Cointe \& Nadaï, 2018).
Obviously, the change in the political landscape has affected many companies with many companies now having set up RE departments when previously they had none. The whole situation is very different from 2009 when the 2020 package was adopted (17). If the policy preferences for RE support reflect the position of the RE departments, but not necessarily the view of the company as a whole, this can also be an explanation for the shift in policy preferences.

The Commission has also shifted their position on RE support since they announced their strategy to phase out RE support schemes by 2030 in the State Aid Guidelines (Commission, 2014). In the revised RE Directive (2018/2001) adopted in December 2018, MSs are still allowed to apply support schemes (Art. 4). According to one market expert, this reflects the broader position of the Commission, which acknowledges that it is difficult to build renewables without support and to set a deadline for when to phase out support schemes. The timing for ruling out subsidies completely depends on many different factors, including country geography, national framework conditions, and the ETS price (17). This discussion is illustrative for the debate about whether and when these technologies can be characterized as mature.

Finally, it should be considered whether publicly announced RE strategies and high RE ambitions belongs to a market strategy of the companies, in which they employ selective disclosure or even greenwashing. For instance, RWE expressed quite high RE ambitions, which is questionable given their strong coal portfolio. However, shortly after the consultation, RWE split into RWE and Innogy, the latter promoting itself as a green energy company, which could have explained the RE preference. A closer look at Innogy's strategy reveals that it is primarily a retail electricity company, with limited, although renewable, production capacity (3,9 GW in 2017) (Innogy, 2018). Another example is Total, who promotes itself as a global leader within solar energy, and strongly advocates continued advantages for RE producers in the CEP. Even though they pursue an ambitious solar strategy, their main business is still within oil and gas (TOTAL, 2018). Whether their solar business is part of a market strategy of the company as a whole is outside the scope of this article.

Despite the economic interest of utilities in high $\mathrm{CO}_{2}$ prices, interviewees disagree that the ETS is used as a strategy to prevent RE deployment. However, one of them acknowledges that some actors have done this in the past when claiming that the ETS should be the only instrument. Hence, one could also assume that those who were against a RE target would be more critical about RE support. 16 argues that the reason they did not lobby actively for a distinct RE target was that they want the GHG emissions reduction target to play a superior role in the climate policy framework. They perceive the solution to be a mix of technologies, in which a fuel switch from coal to gas and nuclear might play a role.

Summing up, what initially appears as inconsistency in policy preferences of many utilities can be 
explained by organizational factors, i.e. endogenously driven changes in business strategies by these actors, which has influenced the companies towards divesting from coal and investing heavily in RE. This trend is highly related to external drivers, both non-market such as regulatory frameworks and policy targets, but also market factors including consumer demand. Whether or not these strategies are also part of a market strategy cannot be judged within the frames of this study, but for those utilities still active in fossil fuel and nuclear energy, this possibility cannot be excluded.

\section{Discussion and Conclusion}

This article systematically assesses the policy preferences of five non-governmental groups of actors within EU electricity policy across three policy processes. It finds that for four groups, preferences remain stable across policy processes. In the ETS reform process, industry associations, traders, and the electricity industry advocated that the ETS should be the main climate policy instrument. In this vein, they mobilize arguments set out by the economists, i.e., that additional policies are inconsistent with the ETS. In the 2030 Framework, the same groups argued almost univocally against a distinct RE target. This contrasted the positions of E-NGOs and the RE industry, claiming that the ETS is insufficient to drive RE deployment and that a mix of several different instruments is needed to enable the energy transition. For these actors, the ETS and RE policies were perceived as consistent and coherent, with many highlighting the need for a broad portfolio of measures in line with the arguments of innovation literature. However, in the CEPprocess, several utilities (group D) adopted a middle position between the conventional utilities and RE industry. They advocated for the continued support of RE along with the strengthening of the ETS. Several of these actors lobbied against a distinct RE target in the ETS process, but for some reason modified their positions in the CEP-process. Even though this shows that the policy preferences of these actors are inconsistent across policy processes, data from in-depth interviews reveal that the actors themselves do not perceive their shift in position as inconsistent or problematic. For them, it is merely a question of which policies better suit their current portfolio and business strategy.

The positions occupied by this group of 'pro-RE' utilities (group D) represent something new in EU energy policy. Even though their positions approach the positions of RE associations and E-NGOS (group A), they stand out as being far more market-oriented and having much stronger ETS-preferences. Whereas group A questions whether the ETS will be able to set a proper price signal, group D believes that the ETS could become a main instrument sometime in the future.

For the literature on public policy, the study sheds light on situations in which shifts in policy preferences of many key actors can occur within very short time frames.
Such rapid changes among a large number of actors are not well documented in the literature and deserve further attention. The limited scope of this article does not allow for elaboration regarding the theoretical implications of the findings, but a fruitful avenue might be to integrate concepts from the transitions literature into institutional theory for conceptualizing such dynamics.

For policymakers, it is important to acknowledge that large electricity industry actors are moving from having an 'either-or' position on climate policy to advocating that RE support can actually be combined with the ETS. This is also a question about choosing the correct policy design elements for the ETS, which succeeded, at least to some extent, with the MSR and permanent cancellation of surplus allowances. With the adoption of the revised ETS-directive, the argument that 'RE policies destroy the ETS' will no longer hold water. Provided with more consistency in the policy mix, the call for a rapid phase-out of RE subsidies might weaken, which might increase acceptance for continued RE policies. This is important given that RE is still a niche technology in many European countries, which points to the need for continued support. Moreover, the findings suggest that the number of pro$\mathrm{RE}$ actors is growing, which increases momentum for the energy transition. This is also confirmed by the interviews. Policymakers could exploit these developments to introduce more ambitious policies in line with calls from science for rapid decarbonization (IPCC, 2018).

For the literature on policy mixes for sustainability transitions, the analysis shows the need to also study the interaction between policies from a policy preference point of view. It also provides new evidence on the key role which cap-and-trade systems might take in advanced transitions. A further contribution to the transitions literature is to show empirically how the energy transition is entering a stage in which several incumbents define themselves as key actors within RE. As a result, these actors will also try to pull the transition in a direction which is favorable for them, into what Lindberg et al. (2018) have called a 'low-disruption transitions pathway'. It remains to see whether this will happen at the cost of smaller and private RE producers, or whether these two developments can take place in parallel.

There are several interesting issues for further research. For the transition literature, it would be interesting to study the processes within the firms that have decided to change their strategies. It is likely that the discussion about whether and when RE-support should be abolished takes place also within companies with diverse portfolios, who are forced to balance their interests across these needs. Since the companies want to speak with one voice publicly, other methods would be needed to acquire more information about these intraorganizational tensions.

Another pressing task is to capture the policy preferences of another type of electricity producers which was clearly underrepresented in this study: the smallscale producers and prosumers (only represented to 
some extent through the RE associations and CEDEC). These types of actors have contributed strongly to the energy transition, but have different needs than the incumbents when it comes to support and regulations. Scholars should pay attention to whether the incumbents will manage to pull the policy mix for the energy transition in their preferred direction, or whether these small players can find ways to maintain their role in this unfolding transition. Further research is needed to analyze the policy mix preferences for different types of actors, for identifying coalitions between these types of actors and assessing their influence in the contested EU energy and climate policy processes.

\section{Acknowledgments}

This research has been made possible by a grant from The Norwegian Research Council for the project "Integration of Power Transmission Grids" (InGrid, Grant number 24 3994/E20). I would like to thank the three anonymous reviewers and the Editor Kacper Szulecki for helpful comments to this article. Further, I would like to thank the interviewees for sharing their knowledge and perspectives. My final thanks go to Elin Lerum Boasson, Mònica Guillen-Royo and Stefan Ćetković for valuable advice and helpful discussions. All errors remain mine.

\section{Conflict of Interests}

The author declares no conflict of interests.

\section{References}

Berger, P. L., \& Luckmann, T. (1966). The social construction of reality. A treatis in the sociology of knowledge. London: Penguin Books.

Boasson, E. L., \& Wettestad, J. (2013). EU climate policy: Industry, policy interaction and external environment. Surrey: Ashgate.

Böhringer, C., \& Rosendahl, K. E. (2010). Green promotes the dirtiest: On the interaction between black and green quotas in energy markets. Journal of Regulatory Economics, 37(3), 316-325.

Cointe, B., \& Nadaï, A. (2018). Feed-in tariffs in the European Union. Cham: Palgrave Macmillan.

Del Río, P. (2014). On evaluating success in complex policy mixes: The case of renewable energy support schemes. Policy Sciences, 47(3), 267-287.

Delmas, M. A., \& Burbano, V. C. (2011). The drivers of greenwashing. California Management Review, 54(1), 64-87.

Delmas, M. A., \& Toffel, M. W. (2008). Organizational responses to environmental demands: Opening the black box. Strategic Management Journal, 29(10), 1027-1055.

DONG Energy. (2013). Consultation response on Green Paper on "A 2030 framework for climate and energy policies". Gentofte, Denmark.
Edmondson, D. L., Kern, F., \& Rogge, K. S. (2018). The co-evolution of policy mixes and socio-technical systems: Towards a conceptual framework of policy mix feedback in sustainability transitions. Research Policy. https://doi.org/10.1016/j.respol.2018.03.010

European Commission. (2001). Proposal for a directive of the European Parliament and of the Council establishing a scheme for greenhouse gas emission allowance trading within the Community and amending Council Directive 96/61/EC. COM(2001) 581 final. Brussels: European Commission.

European Commission. (2014). Guidelines on state aid for environmental protection and energy 2014-2020 (2014/C 200/01). Communication from the Commission. Brussels: European Commission.

European Commission. (2016). Proposal for a directive on common rules for the internal market in electricity. $\operatorname{COM(2016)} 864$ final/2. Brussels: European Commission.

European Commission. (2018a). 2050 long-term strategy. Retrieved from https://ec.europa.eu/clima/ policies/strategies/2050_en

European Commission. (2018b). Revision for phase 4 (2021-2030). Retrieved from https://ec.europa.eu/ clima/policies/ets/revision_en

Fagerberg, J. (2017). Mission (im)possible? The role of innovation (and innovation policy) in supporting structural change \& sustainability transitions (TIK working papers on innovation studies no. 20180216). Oslo: TIK Centre for Technology, Innovation and Culture.

Fankhauser, S., Hepburn, C., \& Park, J. (2010). Combining multiple climate policy instruments: How not to do it. Climate Change Economics, 1(3), 209-225.

Fischer, C., \& Newell, R. G. (2008). Environmental and technology policies for climate mitigation. Journal of Environmental Economics and Management, 55(2), 142-162.

Fitch-Roy, O. W. F. (2017). Negotiating the EU's 2030 climate and energy framework: Agendas, ideas and European interest groups (Unpublished doctoral dissertation). University of Exeter, Exeter, UK.

Flanagan, K., Uyarra, E., \& Laranja, M. (2011). Reconceptualising the 'policy mix' for innovation. Research Policy, 40, 702-713.

Fouquet, D., \& Johansson, T. B. (2008). European renewable energy policy at crossroads-Focus on electricity support mechanisms. Energy Policy, 36(11), 4079-4092.

Geels, F. W. (2011). The multi-level perspective on sustainability transitions: Responses to seven criticisms. Environmental Innovation and Societal Transitions, 1(1), 24-40.

Goulder, L. H. (2013). Markets for pollution allowances: What are the (new) lessons? Journal of Economic Perspectives, 27, 87-102.

Guillen-Royo, M. (2007). Consumption and wellbeing: Motives for consumption and needs satisfiers in Peru (Unpublished doctoral dissertation). University of 
Bath, Bath, UK.

Gullberg, A. T. (2013). Lobbying for renewable energy targets in the European Union. Review of Policy Research, 30(6), 611-628.

Hall, P. A., \& Taylor, R. C. R. (1996). Political science and the three new institutionalisms. Political Studies, 44(5), 936-957.

Hellsmark, H., \& Söderholm, P. (2017). Innovation policies for advanced biorefinery development: Key considerations and lessons from Sweden. Biofuels, Bioproducts and Biorefining, 11(1), 28-40.

Howlett, M., \& Rayner, J. (2007). Design principles for policy mixes: Cohesion and coherence in 'new governance arrangements'. Policy and Society, 26(4), 1-18. Innogy. (2018). Annual report 2017. Essen: Innogy.

IPCC. (2018). Summary for policymakers. In M. MassonDelmotte, P. Zhai, H. O. Pörtner, D. Roberts, J. Skea, P. R. Shukla, ... T. Waterfields (Eds.), Global warming of $1.5^{\circ} \mathrm{C}$ (pp. 3-26). Geneva: World Meteorological Organization.

Jarke, J., \& Perino, G. (2017). Do renewable energy policies reduce carbon emissions? On caps and inter-industry leakage. Journal of Environmental Economics and Management, 84, 1-58.

Kemp, R. (2011). Ten themes for eco-innovation policies in Europe. SAPIENS, 4(2). Retrieved from http://journals.openedition.org/sapiens/1169

Kemp, R., Schot, J., \& Hoogma, R. (1998). Regime shifts to sustainability through processes of niche formation: The approach of strategic niche management. Technology Analysis \& Strategic Management, 10(2), 175-198.

Lindberg, M. B., Markard, J., \& Andersen, A. D. (2018). Policies, actors and sustainability transition pathways: A study of the EU's energy policy mix. Research Policy. https://doi.org/10.1016/j.respol.2018.09.003

March, J. G., \& Olsen, J. P. (1989). Rediscovering institutions. The organizational basis of politics. New York, NY: The Free Press.

Marquis, C., Toffel, M. W., \& Zhou, Y. H. (2016). Scrutiny, norms, and selective disclosure: A global study of greenwashing. Organization Science, 27(2), 483-504.

Meckling, J. (2011). The globalization of carbon trading: Transnational business coalitions in climate politics. Global Environmental Politics, 11(2), 26-50.

Montelnews. (2018). Graph: EUA price. Retrieved from
https://www.montelnews.com/Controls/Graph/Close Volume/CloseVolumeGraph.aspx?CommodityID=722 \&Symbol=FEUA122018\&IsBroker=False

Moravcsik, A. (1998). The choice for Europe: Social purpose and state power from Messina to Maastricht. Ithaca, NY: Cornell University Press.

Nelson, R. R., \& Winter, S. G. (1977). In search of useful theory of innovation. Research Policy, 6(1), 36-76.

Rogers, E. (1996). The diffusion of innovations. New York, NY: Free Press.

Rogge, K. S., Kern, F., \& Howlett, M. (2017). Conceptual and empirical advances in analysing policy mixes for energy transitions. Energy Research \& Social Science, 33, 1-10.

Rogge, K. S., \& Reichardt, K. (2016). Policy mixes for sustainability transitions: An extended concept and framework for analysis. Research Policy, 45(8), 1620-1635.

Scharpf, F. W. (2000). Institutions in comparative policy research. Comparative Political Studies, 33(6/7), 762-790.

Skjærseth, J. B., Eikeland, P. O., Gulbrandsen, L. H., \& Jevnaker, T. (2016). Linking EU climate and energy policies: Decision-making, implementation and reform. Cheltenham: Edward Elgar.

Smith, A., \& Raven, R. (2012). What is protective space? Reconsidering niches in transitions to sustainability. Research Policy, 41(6), 1025-1036.

Thelen, K. (1999). Historical institutionalism in comparative politics. Annual Review of Political Science, 2, 369-404.

TOTAL. (2018). 2017 registration document including the annual financial report. Courbevoie: TOTAL.

Vos, J. (2009). Actions speak louder than words. Greenwashing in corporate America. Notre Dame Journal of Law, Ethics \& Public Policy, 23, 673-698.

Wettestad, J., \& Jevnaker, T. (2016). Rescuing EU emissions trading. The climate policy flagship. London: Palgrave Macmillan.

Wrake, M., Burtraw, D., Lofgren, A., \& Zetterberg, L. (2012). What have we learnt from the European Union's emissions trading system? Ambio, 41(Suppl. 1), 12-22.

Ydersbond, I. M. (2014). Multilevel 'venue shopping': The case of EU's Renewables Directive. Interest Groups \& Advocacy, 3(1), 30-58.

\section{About the Author}

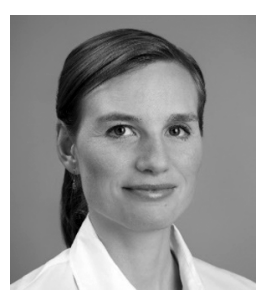

Marie Byskov Lindberg is a PhD Candidate in innovation studies at the University of Oslo. In her PhD project, she studies the energy transition in the EU with a particular focus on policy processes relating to power markets, renewable energy deployment, electricity grids, and interconnectors. Before starting her PhD, she held positions as a climate policy analyst and policy advisor at Climate Analytics (Germany), ZERO (Norway) and the Federal Ministry for the Environment (Germany). 


\section{COgITATIO}

Annex

Table A. List of interviewees.

\begin{tabular}{llll}
\hline Interviewee & Position in organisation & Type of organisation & Date \\
\hline Interviewee 1 & Policy advisor & $\begin{array}{l}\text { Eurelectric-umbrella association } \\
\text { for European electricity industry }\end{array}$ & November, 2017 \\
\hline Interviewee 2 & Policy advisor & Renewable energy association & November, 2017 \\
\hline Interviewee 3 & Policy advisor & Renewable energy association & November, 2017 \\
\hline Interviewee 4 & Head of Department & Utility & September, 2018 \\
\hline Interviewee 5 & EU Regulatory affairs & Utility & January, 2019 \\
\hline Interviewee 6 & EU Regulatory affairs & Utility & January, 2019 \\
\hline Interviewee 7 & Former Policy Officer & EU energy policy expert & January, 2019 \\
\hline
\end{tabular}

Table B. Consultations used as data source for this study.

\begin{tabular}{llll}
\hline Initiated by & Name of consultation & Consultation period & Abbreviation \\
\hline DG Climate & $\begin{array}{l}\text { Consultation on structural options to } \\
\text { strengthen the EU Emissions Trading System }\end{array}$ & December 2012 to February 2013 & ETS 2013 \\
\hline DG Energy & $\begin{array}{l}\text { Consultation on climate and energy policies } \\
\text { until 2030 }\end{array}$ & March 2013 to July 2013 & 2030 Framework \\
\hline DG Climate & $\begin{array}{l}\text { Consultation on Emission Trading System (ETS) } \\
\text { post-2020 carbon leakage provisions }\end{array}$ & May 2014 to July 2014 & ETS 2014 \\
\hline DG Climate & $\begin{array}{l}\text { Consultation on revision of the EU Emission } \\
\text { Trading System (EU ETS) Directive }\end{array}$ & December 2014 to March 2015 & ETS 2015 \\
\hline DG Energy & Consultation on a new Energy Market Design & July 2015 to October 2015 & EMD \\
\hline DG Energy & $\begin{array}{l}\text { Preparation of a new Renewable Energy } \\
\text { Directive for the period after 2020 }\end{array}$ & November 2015 to February 2016 & RED \\
\hline
\end{tabular}


Table C. Policy preference-ranking values for each dimension.

1.1 Lead question: The ETS should be the main instrument for the EU's energy transition

$1.1-1=$ Yes, the ETS is fundamental and should be the main instrument.

$1.1-2$ = Rather yes, ETS is important. In principle, it should be the main instrument.

$1.1-3=$ Rather no, the ETS is not sufficient. We may need other instruments as well.

$1.1-4=$ No, the ETS is not sufficient to ensure the energy transition and will not be so in foreseeable future.

\subsection{Lead question: Should there be support for RE after 2020?}

$1.2-1=$ No, RE support should be eliminated

1.2 - 2 = Rather no, but in some cases we may need (strongly) delimited support. Support to 'mature technologies' should be removed.

1.2 - 3 = Rather yes, we still need some sort of support post 2020

$1.2-4$ = Yes, RE support is inevitable to ensure we reach the 2030 targets. Prefer exemptions from balancing responsibilities and merit order dispatch.

2.1 Lead question: Do we need to strengthen the ETS? (permanent removal of surplus/include backloaded allowances in the MSR)? Higher LRF than EC proposal $>2.2 \%$ ?

$2.1-1$ = No, the ETS is working well and will achieve its objective for 2020 (Or: the cap for 2030 is already too high).

$2.1-2$ = Rather no, there is not much need to strengthen the ETS. Any adjustment should not come before 2020.

$2.1-3$ = Rather yes, we need the MSR and support the suggestion for a tighter LRF (as suggested by EC).

$2.1-4$ = Yes, we need a rapid introduction of the MSR (before 2020)/permanent removal of surplus allowances/a higher LRF than suggested by the EC (>2,2\%).

2.2 Lead question: Should there still be free allowances after 2020 and, if yes, how large should this share of the post-2020 allowance budget be?

$2.2-1=$ Yes, there should be no limit to free allowances for industry.

$2.2-2=$ Yes, higher or same share of free allowances in phase 4 (post 2020) as in phase 3 (2012-2020).

$2.2-3=$ Yes, lower share in phase 4 than in phase $3 /$ based on efficiency benchmarks that provide incentives for GHG reductions

$2.2-4=$ No, as a general rule, there should be no free allowances. Only if it can be proved that carbon leakage is a real issue.

3.1 Lead question: RE deployment is of greatest importance and we need to increase the pace of RE deployment.

$3.1-1=$ No, RE is currently sufficiently deployed (in the EU)

$3.1-2$ = Rather no, we might deploy a bit more in some regions, but no need to speed up deployment

$3.1-3=$ Rather yes, we need to increase RES shares

$3.1-4=$ Yes, we must aim for a renewable energy system and we need to speed up deployment to achieve this

\subsection{Lead question: RE is sufficiently (or over-exploited) deployed in the EU}

$3.2-1=$ Yes, potential for further RE is very limited.

$3.2-2=$ Rather yes, RE is quite well deployed and further potential is confined, at least in some areas.

$3.2-3$ = Rather no, there is potential for more RE

$3.2-4=$ No, there is a huge potential for much more RE in the EU

3.3 Lead question: We need ambitious RE targets and to make sure we reach these targets.

3.3 - 1 = No, there is no need for ambitious RE targets.

$3.3-2=$ Rather no, RE is developing fine as it is.

$3.3-3=$ Rather yes. We need to make sure that we have some targets for RE.

3.3 - 4 = Yes, we need ambitious (and preferably binding) targets for RE and make sure we reach these targets.

3.4 Lead question: RE deployment is a reason for increased system costs and energy prices

$3.4-1=$ Yes, RE are very expensive and increase the cost of system and consumer prices

$3.4-2=$ Rather yes, RE lead to higher costs.

$3.4-3=$ Rather no, RE are not the main reason why costs increase

$3.4-4=$ No, conventional energy is also expensive and we need to invest in the energy system anyways. 
Table D. Groups of actors and quotes from consultation responses.

\begin{tabular}{|c|c|c|c|c|}
\hline $\begin{array}{l}\text { Policy } \\
\text { preference } \\
\text { group }\end{array}$ & GROUP A & GROUP D & GROUP B & GROUP C \\
\hline Actor type & $\begin{array}{l}\text { E-NGOs, } \\
\text { RE associations }\end{array}$ & Electricity industry & Electricity industry & $\begin{array}{l}\text { Industry, business } \\
\text { associations }\end{array}$ \\
\hline $\begin{array}{l}\text { Quotes } \\
\text { on ETS } \\
\text { (examples) }\end{array}$ & $\begin{array}{l}\text { WWF warns strongly } \\
\text { against a carbon } \\
\text { market 'orthodoxy' } \\
\text { where the Commission } \\
\text { would perpetuate the } \\
\text { notion that the EU ETS } \\
\text { can deliver all the } \\
\text { needed emission } \\
\text { reductions in a timely } \\
\text { manner on its own. No } \\
\text { single policy } \\
\text { instrument can be left } \\
\text { alone to achieve this } \\
\text { complex and } \\
\text { multi-faceted task } \\
\text { since it cannot correct } \\
\text { all the relevant market } \\
\text { failuresIn particular, } \\
\text { the EU ETS must be } \\
\text { framed as having its } \\
\text { rightful place in an } \\
\text { optimal mix of policy } \\
\text { instruments in the pre } \\
\text { and post 2020 context. } \\
\text { (WWF, ETS, 6.2) } \\
\text { The EU ETS must be } \\
\text { reformed boldly if it is } \\
\text { remain too low even } \\
\text { beyond } 2030 \text { ). (CAN, } \\
\text { tallowants out of operation } \\
\text { RED, p. 12) } \\
\text { effective policy } \\
\text { instrument. Otherwise } \\
\text { it will remain a } \\
\text { toothless paper tiger } \\
\text { that fails to adequately } \\
\text { drive the } \\
\text { decarbonisation of } \\
\text { European industry. } \\
\text { However, the EU ETS } \\
\text { alone will not be able } \\
\text { to deliver the } \\
\text { necessary incentives to } \\
\text { decarbonize the EU. } \\
\text { (E3G, ETS) } \\
\text { Ihe ETS will not force } \\
\text { land }\end{array}$ & $\begin{array}{l}\text { Ideally RES support } \\
\text { schemes should be } \\
\text { phased out, but this } \\
\text { requires that the ETS } \\
\text { will start to become } \\
\text { relevant as a proper } \\
\text { pricing of } \mathrm{CO}_{2} \text { (Dong, } \\
\text { RED, p. 12) } \\
\text { Even though different } \\
\text { drivers (such as } \mathrm{CO}_{2} \\
\text { price and market } \\
\text { forces) could ensure } \\
\text { the development of } \\
\text { renewable sources in } \\
\text { the market, a gap } \\
\text { versus the [EU RES] } \\
\text { target could still } \\
\text { remain. (Enel, EMD, } \\
\text { p. 9) } \\
\text { Although carbon } \\
\text { pricing should be the } \\
\text { main driver for } \\
\text { decarbonisation } \\
\text { investments, the } \\
\text { existence of a } \\
\text { quantitative RES target, } \\
\text { together with an ETS } \\
\text { so far incapable of } \\
\text { giving a sound CO } 2 \\
\text { price signal for } \\
\text { decarbonisation, } \\
\text { points to the need for } \\
\text { continuing RES support } \\
\text { schemes. (Iberdrola } \\
\text { EMD, Executive } \\
\text { Summary p. } 1 \text { ) }\end{array}$ & 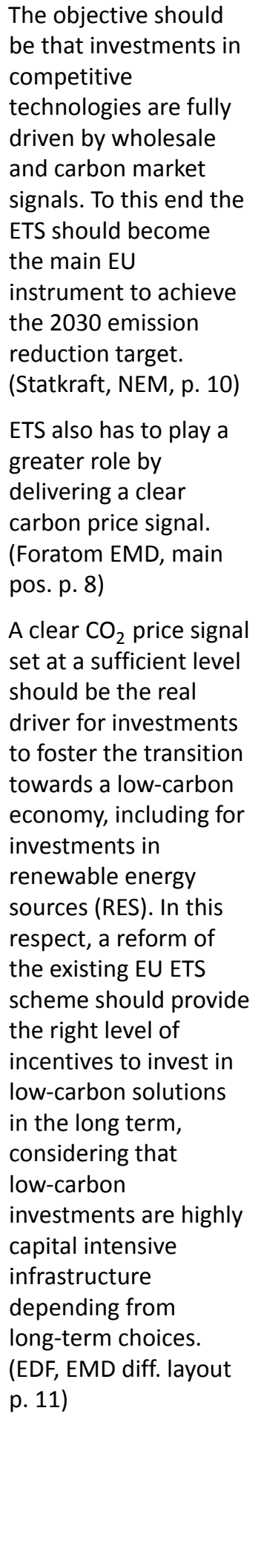 & $\begin{array}{l}\text { A successful EU ETS is } \\
\text { important as it } \\
\text { provides clear market } \\
\text { signals for all } \\
\text { low-emission } \\
\text { technologies. } \\
\text { (Euracoal, EMD, p. 8) } \\
\text { The ETS is delivering its } \\
\text { objective for 2020: the } \\
\text { ETS sector will reduce } \\
\text { its CO }{ }_{2} \text { emissions by } \\
21 \% \text { compared with a } \\
2005 \text { baseline in a } \\
\text { cost-effective and } \\
\text { economically efficient } \\
\text { way. (Euracoal, EMD, } \\
\text { p. } 6 \text { ) } \\
\text { The climate policy in } \\
\text { the electricity } \\
\text { generation sector is } \\
\text { directed by EU ETS } \\
\text { which is aiming at } \\
\text { carbon reductions at } \\
\text { the lowest cost. The } \\
\text { ETS fits into a broader } \\
\text { energy and climate } \\
\text { policy aiming at } \\
\text { guaranteeing secure, } \\
\text { competitive and } \\
\text { sustainable-energy. } \\
\text { (IFIEC, RED, p. 7) }\end{array}$ \\
\hline
\end{tabular}


Table D. (Cont.) Groups of actors and quotes from consultation responses.

\begin{tabular}{|c|c|c|c|c|}
\hline $\begin{array}{l}\text { Policy } \\
\text { preference } \\
\text { group }\end{array}$ & GROUP A & GROUP D & GROUP B & GROUP C \\
\hline Actor type & $\begin{array}{l}\text { E-NGOs, } \\
\text { RE associations }\end{array}$ & Electricity industry & Electricity industry & $\begin{array}{l}\text { Industry, business } \\
\text { associations }\end{array}$ \\
\hline $\begin{array}{l}\text { Quotes on RE } \\
\text { support } \\
\text { (examples) }\end{array}$ & $\begin{array}{l}\text { National support } \\
\text { should continue to be } \\
\text { part of the EU climate } \\
\text { and renewable energy } \\
\text { policy as we move } \\
\text { towards } 2030 \text {. Steady } \\
\text { and continuous RE } \\
\text { deployment requires } \\
\text { stable and credible } \\
\text { framework conditions } \\
\text { that build on a robust } \\
\text { governance } \\
\text { mechanism. (BEE, } \\
\text { EMD, p. 9) } \\
\text { The national support } \\
\text { schemes adopted by } \\
\text { EU member states } \\
\text { have been } \\
\text { instrumental in the } \\
\text { deployment of } \\
\text { renewable energy in } \\
\text { recent years. They will } \\
\text { continue to play an } \\
\text { important role in } \\
\text { ensuring the required } \\
\text { investments for } \\
\text { reaching the } 2030 \\
\text { targets. The RED } \\
\text { review should } \\
\text { maintain provisions } \\
\text { mandating the } \\
\text { adoption of support } \\
\text { schedicated targets and } \\
\text { support measures. } \\
\text { (WWF, ETS, 6.2) } \\
\text { RED p. } 6 \text { ) } \\
\text { There will be a } \\
\text { continued need to } \\
\text { ensure Europe can } \\
\text { focus on no-regret } \\
\text { measures [for } \\
\text { decarbonisation] such } \\
\text { as the deployment of } \\
\text { enewable energy and } \\
\text { sfficiency at } \\
\text { denpeace }\end{array}$ & $\begin{array}{l}\text { All support systems for } \\
\text { electricity from } \\
\text { renewable sources } \\
\text { (RES-E) in line with the } \\
\text { Environmental and } \\
\text { Energy state Aid } \\
\text { Guidelines (EEAG) shall } \\
\text { determine the support } \\
\text { level by competition. } \\
\text { Hence production } \\
\text { targets are a necessity } \\
\text { to determine the } \\
\text { volume (MW typically } \\
\text { for Feed-in Premium } \\
\text { systems with tenders } \\
\text { or MWh for RES quota } \\
\text { systems) beforehand. } \\
\text { (Vattenfall, RES p. 9) } \\
\text { The principle of } \\
\text { priority access and } \\
\text { dispatch enshrined in } \\
\text { the RED should be } \\
\text { maintained after 2020 } \\
\text { (Total, RED, p. 30) } \\
\text { Support schemes will } \\
\text { still be needed for RES } \\
\text { technologies under } \\
\text { development, and in } \\
\text { the industrialisation } \\
\text { phase towards costs } \\
\text { that are similar to } \\
\text { expected market } \\
\text { revenues. (Dong, RED, } \\
\text { p. } 12 \text { ) } \\
\text { Support schemes will } \\
\text { probably still be } \\
\text { needed to achieve the } \\
\text { 2030 EU targets but } \\
\text { need to evolve } \\
\text { towards more cost } \\
\text { effective competitive } \\
\text { schemes leading to } \\
\text { long term contracts. } \\
\text { (Enel RED, p. 12) }\end{array}$ & $\begin{array}{l}\text { Policies should be } \\
\text { immediately reformed } \\
\text { to make RES fit for } \\
\text { market. This means } \\
\text { applying to RES the } \\
\text { same rights and } \\
\text { obligations of market } \\
\text { participation as other } \\
\text { market participants } \\
\text { (operational } \\
\text { integration of RES). } \\
\text { (Foratom EMD, main } \\
\text { pos. p. } 8 \text { ) } \\
\text { A clear rule should be } \\
\text { that all remaining } \\
\text { subsidies for mature } \\
\text { technologies must be } \\
\text { phased out at the end } \\
\text { of the current subsidy } \\
\text { schemes or at the } \\
\text { latest after } 2020 \text { when } \\
\text { the CO } 2 \text { price should } \\
\text { be the only driver to } \\
\text { steer decarbonisation } \\
\text { and growth or RES" } \\
\text { (Fortum, EMD, p. } 11 \text { ) } \\
\text { Subsidies should be } \\
\text { made available only } \\
\text { where needed. } \\
\text { Market-ready } \\
\text { technologies should } \\
\text { fully participate in the } \\
\text { market while a } \\
\text { functioning CO } 2 \\
\text { emissions market that } \\
\text { puts a clear price on } \\
\text { externalities will help } \\
\text { pem; (Epex, RED, }\end{array}$ & $\begin{array}{l}\text { Heavily subsidising } \\
\text { certain technologies } \\
\text { (i.e. the solar boom } \\
\text { leaves a debt to be } \\
\text { paid by German } \\
\text { consumers over the } \\
\text { next } 20 \text { years of } € 100 \\
\text { to } € 200 \text { billion) distorts } \\
\text { the energy market so } \\
\text { much that almost all } \\
\text { other energy sources } \\
\text { are at a disadvantage. } \\
\text { (Euracoal, EMD, p. 6) } \\
\text { RES-E support in many } \\
\text { MSs leads to an } \\
\text { uncoordinated impact } \\
\text { into the functioning of } \\
\text { the electricity market } \\
\text { with negative } \\
\text { consequences for } \\
\text { stability and huge } \\
\text { increase of system } \\
\text { costs. (...) Technologies } \\
\text { that cost } 200-300 \\
\text { percent more than a } \\
\text { product price should } \\
\text { not be rolled out at the } \\
\text { level of the RES target. } \\
\text { (IFIEC, RED, p. 7-8) }\end{array}$ \\
\hline
\end{tabular}

